University of Maryland Francis King Carey School of Law

DigitalCommons@UM Carey Law

2012

\title{
The Illegal Process: Basic Problems in the Making and Application of Censorship
}

James Grimmelmann

University of Maryland Francis King Carey School of Law, jgrimmelmann@law.umaryland.edu

Follow this and additional works at: https://digitalcommons.law.umaryland.edu/fac_pubs

Part of the Internet Law Commons

\section{Digital Commons Citation}

78 Dialogue: University of Chicago Law Review Online 58 (2013).

This Article is brought to you for free and open access by the Francis King Carey School of Law Faculty at DigitalCommons@UM Carey Law. It has been accepted for inclusion in Faculty Scholarship by an authorized administrator of DigitalCommons@UM Carey Law. For more information, please contact smccarty@law.umaryland.edu. 


\title{
The Illegal Process: Basic Problems in the Making and Application of Censorship
}

\author{
A Response to Derek E. Bambauer, Orwell's Armchair, 79 U \\ Chi L Rev 863 (2012) \\ James Grimmelmann†
}

The principal question for consideration is whether the United States should enact "[a] statute enabling censorship of Internet material" along the lines described in Bambauer, Orwell's Armchair. ${ }^{1}$ The article will not be reproduced here, although it rewards careful reading. Rather, the present emphasis will be on certain structural features of Professor Bambauer's argument, with particular reference to some of the institutional issues they raise.

\section{INTRODUCTORY NOTES AND QUERIES ON TERMINOLOGY}

1. Professor Bambauer's subject is Internet filtering: how governments do it, what forces constrain it, and what is to be done about it. The essential characteristic of such filtering is that Internet intermediaries-Internet service providers like Comcast and Verizon, search engines like Google and Bing, domain name providers, and the like-design their systems to make some content inaccessible. Professor Bambauer unapologetically describes this filtering as "censorship."2 What justifies the term? Is it simply a matter of linguistic precision, or does the term have a rhetorical force of its own? Given that he is proposing a censorship statute, what explains his willingness to embrace this ordinarily pejorative term?

2. If censorship is the systematic suppression of speech, does it matter how a censor acts? Consider the "modalities of regulation" framework described in Lessig, The Law of the Horse:

\footnotetext{
$\dagger$ Visiting Professor of Law, University of Maryland Francis King Carey School of Law; Professor of Law (on leave), New York Law School.

1 Derek E. Bambauer, Orwell's Armchair, 79 U Chi L Rev 863, 930 (2012).

2 See id at 874-75.
} 
What Cyberlaw Might Teach. ${ }^{3}$ Professor Lessig argues that from the regulator's perspective, the four modalities-law, norms, markets, and code-are substitutes for each other. What is filtering, then, but code-based online censorship? Compare an offline censor who burns books or cuts words out of letters with an online censor who cuts network links or blocks packets. Does the analogy hold? Does it shed any light on Professor Bambauer's use of the term "censorship?"

\section{Notes AND QuerIES ON HARD AND SOFT CENSORShIP}

1. Orwell's Armchair opens with an analytical distinction that will be central to what follows: between "hard" and "soft" forms of censorship through filtering. ${ }^{4}$ There are two forms of hard censorship:

In direct control, the government installs filters on computer infrastructure that it owns. ${ }^{5}$

In deputization, the government orders private intermediaries to install filters on infrastructure that they own. ${ }^{6}$

They are contrasted with three forms of soft censorship:

In pretext, the government uses unrelated laws to impose filtering. ${ }^{7}$

In payment, the government offers rewards to intermediaries who install filters. 8

In persuasion, the government uses the bully pulpit to pressure intermediaries to install filters. ${ }^{9}$

What justifies the labels of "hard" and "soft?" All filters are code. The reader who is unable to obtain a copy of Emmanuel Goldstein's The Theory and Practice of Oligarchical Computation because of Internet filtering is equally unable whether the filter is mandated by law or "voluntarily" deployed by a nominally private actor. Would it be more accurate to say that what is firmer or

3 Lawrence Lessig, The Law of the Horse: What Cyberlaw Might Teach, 113 Harv L Rev 501, 507-11 (1999).

4 Bambauer, 79 U Chi L Rev at 870-71 (cited in note 1).

Id at 875-78.

Id at $878-83$.

Id at 883-87.

Bambauer, 79 U Chi L Rev at 887-91 (cited in note 1).

9 Id at 891-99. 
squishier is the nature of governmental influence on the persons who control the filter code? To say that the distinction is between direct and indirect forms of control over filtering? To say that Professor Bambauer is making not merely a procedural point about how censorship happens but also an institutional point about who does the censoring?

2. Professor Bambauer argues that the government's use of hard censorship is substantially more constrained by law than its use of soft censorship. ${ }^{10}$ If so, who is it that is doing the constraining? Comrade O'Brien seems unlikely to respect the Constitution simply because it is the Constitution. He will have to be reined in by the courts, will he not? And courts' willingness to take up these reins will depend on the strength or weakness of their institutional position and the strength or weakness of the popular consensus against the pernicious ideas contained in Goldstein's tract. If the sober jurisprudential conversation posited in Orwell's Armchair is a conversation that can only take place in certain political and institutional climates, does it seem likely that the present United States is such a climate? Does the collapse of the proposed filter-mandating Stop Online Piracy Act $^{11}$ (SOPA) in January 2012 due to vehement popular protests count as pretty good evidence that it is?

3. Why might it be that the law is hard on hard censorship but soft on soft censorship? Is this a simple failure of the judiciary to do its job of policing the legislature and executive in cases where the latter have not acted according to law? Is the greater difficulty of checking soft censorship through law reflective of an inherent institutional incapacity on the part of the judiciary?

a. What is deputization but official censorship plain and simple? Is there anything to distinguish ordering Verizon to install anti-Goldstein filters from ordering a bookstore to remove his book from its shelves? Is there any possibility that the courts would now make such a distinction? Was there ever a time when there was, and if so, what has changed?

b. Is direct control truly out of the question? Does the fact that most Internet infrastructure is privately owned mean that the public-forum question has never been squarely posed? If Comrade O'Brien were to nationalize the Ameri-

10 Bambauer, 79 U Chi L Rev at 926-27 (cited in note 1).

11 HR 3261, 112th Cong, 1st Sess, in 157 Cong Rec H 7133 (Oct 26, 2011), online at http://www.gpo.gov/fdsys/pkg/BILLS-112hr3261ih/pdf/BILLS-112hr3261ih.pdf (visited Feb $16,2013)$. 
can portions of the Internet and install filters, is there any serious question about the outcome of the resulting First Amendment challenge?

c. Should we perhaps understand pretext as hard censorship in sheep's clothing? Given that the very point of pretext is to circumvent the normal limits on legislative action, it can hardly be presumptuous to expect the courts to look behind pretextual rationales and judge legislation according to its actual effects. Or can it?

d. Do payment and persuasion stand on somewhat different ground because the legislature acts through means other than the creation of primary private duties? What is it about the use of the power to appropriate and the power to jawbone that renders them less susceptible to oversight?

\section{Notes AND QUERIES ON LEGITIMATE AND ILLEGITIMATE CENSORSHIP}

1. Professor Bambauer argues that it is possible to distinguish "legitimate" from "illegitimate" censorship. In particular, he writes, "Legitimate censorship has four virtues: it is openly described, transparent about what it restricts, narrow in the material to which it applies, and accountable to the people it seeks to protect." 12 Can there be any serious question that accountable censorship is better than unaccountable censorship, that focused censorship is better than clumsy censorship, and so on? How general are these propositions? Are they specific to censorship, or are they applications of more general legal norms?

2. Professor Bambauer refers to his criteria as a "process" based methodology"13 and defends them as being "compatible with divergent views on what material should be banned." 14 How far can procedural criteria go in settling questions about censorship? Does it follow that because procedurally regular censorship is more legitimate than procedurally irregular censorship, it is legitimate in an absolute as well as a relative sense? Is this a question that can be settled in the abstract, without reference to the material to be censored? Is it right that whether Winston Smith shall be permitted to read The Theory and Practice of OIigarchical Computation should turn only on the process Comrade O'Brien follows and not on the contents of the book? But if

\footnotetext{
12 Bambauer, 79 U Chi L Rev at 899-900 (cited in note 1).

13 Id at 873.

14 Derek E. Bambauer, Cybersieves, 59 Duke L J 377, 380, 438 (2009).
} 
it is necessary to make normative judgments about whether particular material can appropriately be censored, is it possible to say anything about global censorship that does not rest on contested moral and social values? Is Professor Bambauer's theory an attempt to apply a quintessentially liberal methodologyprocedural justice-to a quintessentially illiberal subjectcensorship?

3. Can Professor Bambauer's procedural criteria be understood in institutional terms? What are openness, transparency, and narrowness but basic conditions that legal norms must fulfill if they are properly to be called "law" at all? And what is accountability but a demand that legal norms must originate from the political branches of government? Is it fair to say that a filtering decision that satisfies the procedural criteria is an institutional settlement of a contested question, that is, a decision duly arrived at as the result of duly established procedures by the institution best suited to make decisions of this type? Is it therefore entitled to deference from other actors in the system, namely courts?

4. Is there something about the structure of filtering decisions that renders them particularly unsuitable for generationas opposed to application-by the courts? One facet of China's experience may be instructive here. The state apparatus responsible for filtering decisions issues ill-defined but binding statements of general (and frequently shifting) policies, which intermediaries are expected to implement on their own. ${ }^{15}$ Dramatic and unpredictable overblocking is the predictable result. Has Professor Bambauer endorsed a clear-statement rule for filtering, under which Congress is permitted to require online censorship but must make its intent unmistakable and provide precise direction when it deviates from a background norm against censorship? Or might it be that a clear statement in favor of censorship is precisely the one thing courts know they must not permit, so that the entire subterfuge of soft censorship is in fact a legal fiction willingly acquiesced in by all parties?

5. Professor Bambauer easily concludes that hard censorship is more legitimate than soft. ${ }^{16}$ How could it be otherwise?

a. Deputization - the creation of primary private $\mathrm{du}^{-}$ ties-will ordinarily require the open and accountable en-

15 See Human Rights Watch (HRW), World Report: 2006 245-47 (HRW and Seven Stories Press 2006), online at http://www.hrw.org/legacy/wr2k6/wr2006.pdf (visited Feb 16, 2013).

16 Bambauer, 79 U Chi L Rev at 930 (cited in note 1). 
actment of legislation. The enforcement of those duties by the judiciary will ordinarily require transparency. Narrowness is a property of the fit between the two. The procedural legitimacy of deputization is almost tautological, is it not?

b. Direct control is an interesting middle case. Does direct control locate day-to-day control of the infrastructure in the executive rather than in the legislature? Is it problematic if it does? How plausible is it that government-operated routers would be open to the kinds of public scrutiny necessary to verify the nature of the filtering actually being engaged in? Would such information properly be the subject of a FOIA request? On what statutory grounds, if any, might Comrade O'Brien colorably deny such a request? Does it matter whether the government is acting as proprietor or as sovereign? Is there a difference? Is direct control just payment writ large? If so, does it still deserve the designation of "hard" censorship?

c. Pretext is by definition illegitimate, is it not? Would the answer change if "pretext" were described instead as "the routine application of general legal norms to online activities?" If a domain name facilitates illegal gambling activity, why should it be any less subject to seizure than other property used in facilitating gambling? Or is this rhetorical shift itself a kind of pretext precisely analogous to the pretext involved in applying anti-gambling laws to domain names? Is the danger that pretext works precisely because labels matter and courts have difficulty looking behind them to understand the actual consequences for speech? On the other hand, is there anything wrong with pretextual legislation or pretextual prosecution, as long as the legislation or prosecution itself could be independently and honestly justified? Put another way, does the focus on pretext inappropriately project a judicial virtue on branches of government where it does not apply? Or is the point that these other branches may act pretextually, but they may not conscript the courts in their rhetorical shell game?

d. After National Federation of Independent Business $v$ Sebelius ${ }^{17}$ do courts now possess meaningful criteria to limit Congress's use of its power of the purse to inhibit speech? ${ }^{18}$ Or is an analysis that depends on distinguishing the gov $^{-}$

$17 \quad 132$ S Ct 2566 (2012).

18 Consider id at 2606-07. 
ernment-as-funder from the government-as-censor necessarily intractable? Consider the similar difficulties besetting campaign finance and telecommunications law, two other areas in which government subsidies for speech coexist uneasily with government regulations of speech. If the power to tax is the power to destroy, is the power to spend the power to censor?

e. Is persuasion the least law-like of the modalities of censorship? Is it anything more or less than the threat of legislation without the substance? Is it better described as corruption? As extortion? Or is it sometimes a form of grandstanding, in which officials take demagogic positions for political gain? If that is right, then does it perhaps score highly on openness since the officials must identify themselves publicly with the censorial goal in order to reap the demagogue's political rewards? And does this suggest that a theory of accountability must include a fairly rich account of the political process and must mean something more than just accountability to a majority of the relevant electorate? Is the problem with persuasion that it permits individual officials to usurp the authority of the institutions to which they belong?

6. Is there a connection between the greater legal constraints on hard censorship and its greater legitimacy? Is the more exacting judicial scrutiny of deputization the cause of its greater adherence to rule-of-law virtues? Or is it the fact that deputization acts through the prototypical mechanisms of law that makes it susceptible to meaningful oversight? Are the forms of governmental action used in soft censorship deviations from the Platonic ideal of lawmaking, or are they indispensable elements of the lawmaking enterprise?

\section{NOTES AND QUERIES ON NONLEGAL CONSTRAINTS ON CENSORSHIP}

1. Law is not the only possible check on official censorship. Professor Bambauer argues that the other three modalitiescode, markets, and norms - should also be understood as ways to limit censorship. ${ }^{19}$ Can law also be an antiregulatory force? If not, what makes it different? Recall Professor Lessig's corollary that law can commandeer the other three modalities for regula-

19 Bambauer, 79 U Chi L Rev at 906-09, 920-26 (cited in note 1). 
tory purposes ${ }^{20}$ and Professor Bambauer's claim that deputization-law mandating code-is a form of hard censorship. If the four modalities are all tools deployed by actors in a complex global ecosystem to influence each others' conduct, what remains of Professor Lessig's original insight that these modalities are regulatory substitutes? Is the answer perhaps that we should be clearer about distinguishing how a regulatory modality is applied to its subject from the political economy of how regulation is developed and deployed? In considering the following questions about the effectiveness of the other antimodalities, due regard should be given to the institutional setting: the reaction by private parties to the situation in which they find themselves as a result of governmental or quasi-governmental action.

a. To what extent are the merits and demerits of code as a check on filtering captured by the phrase "arms race"? Given that software can be replicated and distributed at nearzero cost, how is it that government attempts to target circumvention code can be expected to raise the costs of circumvention? Does the United States' experience with anticircumvention rules in the digital rights management context suggest that legal prohibitions on circumvention tools in the filtering context will be effective or ineffective? ${ }^{21}$ Filtering-circumvention tools are most commonly used today in countries with politically repressive regimes. ${ }^{22}$ Is there anything about this experience that might be unlikely to translate to the United States? If so, what does it imply about the effectiveness of a domestic anticircumvention law?

b. Professor Bambauer points to high concentration in Internet infrastructure markets as a reason that market forces may be an ineffective check on filtering. ${ }^{23}$ What ever happened to "The Net interprets censorship as damage and routes around it"? ${ }^{24}$ How much of this concentration is essential to the existence of a single, unified Internet, and how

\footnotetext{
20 See Lessig, 113 Harv L Rev at 512-13 (cited in note 3).

21 See, for example, Digital Millennium Copyright Act § 103(a), Pub L No 105-304, 112 Stat 2860, 2863-64 (1998), codified at 17 USC § 1201(a) (declaring that "[n]o person shall circumvent a technological measure that effectively controls access" to certain copyrighted materials, and barring distribution of circumvention tools).

22 See, for example Cormac Callanan, et al, Leaping over the Firewall: A Review of Censorship Circumvention Tools 46-57 (Freedom House 2011), online at http://www.freedomhouse.org/sites/default/files/inline_images/Censorship.pdf (visited Feb 16, 2013).

23 Bambauer, $79 \mathrm{U}$ Chi L Rev at 920 (cited in note 1).

24 See Philip Elmer-Dewitt, First Nation in Cyberspace, Time (Dec 6, 1993) (quotation marks omitted) (quoting John Gilmore).
} 
much is the accidental result of historical factors and political choices? If existing intermediaries are unwilling to offer access to censored material for which there is demand, will this create countervailing market pressures for disruptive new intermediaries to develop alternative forms of access? If not, what structural features of these markets might explain their resistance to entry?

c. Professor Bambauer argues that norms are an imperfect constraint on soft censorship because their strength varies with the community and with the material to be blocked. If true, is this fact an argument for or against his processbased methodology? He further argues that clever framing by censors and collective action problems will inhibit the development of antifiltering political movements. What then of the SOPA protests from January 2012?25 Were they an aberrational moment in an otherwise unbroken narrative of public complacency? Is their vehemence to be explained by the fact that it was hard censorship at stake rather than soft? Or do they imply that norms can sometimes be an effective check on soft censorship?

2. Professor Bambauer suggests that it is paradoxical that soft censorship is primarily constrained by practical limits such as the availability of funds rather than by any principled limits. ${ }^{26}$ Is this so surprising in light of his arguments about the absence of principled limits? If soft censorship were truly unconstrained in all ways, would we not expect to see it used with impunity and ubiquity? Since soft censorship remains the exception rather than the norm, must it not be the case that there are some limits on it somewhere? And having ruled out legal limits, should we not expect that the actual limits are pragmatic? Would it be fair to say that while government has many tools at its disposal, none of them are free? That just as payment draws on the public fisc, persuasion also draws on political capital, and that neither can be spent without limit? If all censorship, hard and soft, operates within these budgetary constraints, how might this fact be employed to prevent censorship or to channel it in the direction of greater legitimacy?

25 See Jenna Wortham, Protest on Web Takes On 2 Bills Aimed at Piracy, NY Times A1 (Jan 18, 2012).

26 Bambauer, 79 U Chi L Rev at 926-27 (cited in note 1). 


\section{NOTES AND QUERIES ON THE DRAFTING OF A HYPOTHETICAL INTERNET-FILTERING STATUTE}

1. Professor Bambauer outlines a potential federal Internet filtering statute. ${ }^{27}$ The features and likely effects of such a scheme will be considered presently, but first some attention should be given to the drafter's apparent attitude toward his hypothetical statute. He pointedly declines to endorse the proposition that "interdicting online content is normatively desirable." ${ }^{8}$ But consider the following quotations from his Article:

[I]f hard censorship is more legitimate than soft, and society determines that government should prevent access to certain materials, then the federal government should pass and implement a statutory scheme for online censorship. ${ }^{29}$

...

$[\mathrm{H}]$ ard censorship is normatively preferable to soft censorship. ${ }^{30}$

$\cdots$

[O]nline censorship is inevitable: nearly every government seeks to block some material on the Net. ${ }^{31}$

Does it not follow, by the introduction of a conjunction and the application of modus ponens, that the government should enact a censorship statute? What then is the significance of Professor Bambauer's normative reservation? Should he be understood as arguing that the government is justified in enacting a censorship statute but that he would prefer to be counted as a conscientious objector to it? Or is this a lament about the ubiquity of online censorship coupled with an attempt to make the best of a bad situation?

2. The defining feature of the Bambauer Act is its extensive regime of procedural safeguards. It vests the filtering power exclusively in the US Attorney General, requires prior notice and adjudication before the implementation of any filtering request and regular review afterwards, sets the government's burden of proof at clear and convincing evidence, permits only narrowly tailored blocking, and requires that intermediaries be reimbursed for their compliance costs. ${ }^{32}$ Given Professor Bambauer's

\footnotetext{
27 Id at $927-38$.

28 Id at 927.

9 Id at 868-69.

30 Bambauer, $79 \mathrm{U}$ Chi L Rev at 870 (cited in note 1).

31 Id at 936.

32 Id at 931-35.
} 
proceduralist jurisprudence, are these provisions a surprise? Are there any provisions not on the list that should be added to it? Any on the list that could be safely removed?

3. Can the Bambauer Act be understood in institutional terms? Its provisions naturally break down along institutional lines. Is that a happy accident of how the Act is explained, or does it reflect deeper commitments of the legal philosophy from which it springs?

a. Does restricting filtering authority to the Attorney General reflect a judgment about the competence and motives of the Department of Justice as compared with other possible institutions? Should the Attorney General's authority be delegable? Compare the list of officials authorized to request wiretaps in 18 USC $\S 2516 .{ }^{33}$ Should filtering authority be broader or narrower than wiretapping authority? Do they raise similar intellectual-freedom concerns? Are the two in some sense substitutes for each other?

b. Do the requirements of prior notice, an opportunity to be heard, and review for changed circumstances reflect a judgment about the nature of adjudication, a judgment about judicial independence, or both? Would an adjudicatory proceeding before a filtering tribunal within the Department of Commerce before an Article I administrative law judge suffice? Is it possible to imagine a category of filtering requests so clear-cut, so routine, or so numerous that rulemaking would be a suitable alternative procedure?

c. The Act's choice of a clear-and-convincing burden of proof makes a statement about deference, does it not? Is it fair to say that the entire tenor of the Act bespeaks a profound skepticism of the motives of executive actors and that the Act invites judges to partake of that skepticism? If so, should they extend their scrutiny to matters beyond the quantum of proof required? For example, would it be appropriate for a judge in a filtering case to demand detailed evidence from the government even in the face of a procedural default by the target of a filtering order?

d. Who is best positioned to ensure that a filtering order is narrowly tailored to the material to be blocked? Professor Bambauer's answer is that intermediaries should be charged with implementing the filters "using technically feasible, financially reasonable efforts" and should be reimbursed for 
their efforts. ${ }^{34}$ What institutions, if any, will be in a position to monitor the effectiveness of the filtering as implemented? What effect does cost-shifting have on the private incentives of intermediaries?

e. The entire scheme is shot through with attempts to make filtering orders both open and transparent. To what extent is this goal in tension with the goal of any filtering scheme to make certain material unavailable? How far is it possible to go in detailing what is being blocked without giving away the game? In the face of such concerns, who can be counted on to ensure that the required disclosures really are taking place? It may be instructive to consider the United States' experience with public oversight of executive electronic surveillance, and the courts' experience overseeing the redaction of court filings. ${ }^{35}$

\section{Notes AND QUERIES ON THE EFFECTS OF A HYPOTHETICAL INTERNET-FILTERING STATUTE}

1. How plausible is it that the United States might actually adopt a statute along the lines of the Bambauer Act? Will the Act's rigorous preconditions to filtering orders make it unappealing to parties who simply wish to limit access to the speech that they hate? And how likely is it that free-speech advocates will endorse a statute that purports to authorize official censorship? Is the Act the kind of compromise that is politically feasible because it shares the pain broadly? Or does it fall in an unhappy medium that will satisfy no one? Might Professor Bambauer have other reasons for proposing an Act he personally opposes and that seems unlikely to be enacted?

2. What would actually happen if the Bambauer Act were to be made law? Would Comrade O'Brien seek to employ the hardcensorship powers it grants to the government? Is he likely to be satisfied with the results? Is Professor Bambauer perhaps playing a game of eleven-dimensional chess with Comrade O'Brien by proffering an Act that purports to give him the censorial power he seeks, while channeling him into procedural devices that will be largely ineffective in practice? Or is it more likely that Comrade O'Brien will continue to employ the techniques of soft

\footnotetext{
34 Bambauer, 79 U Chi L Rev at 936 (cited in note 1).

35 Consider Peter A. Winn, Judicial Information Management in an Electronic Age: Old Standards, New Challenges, 3 Fed Courts L Rev 135, 151 (2009) (describing pervasive failures to redact social security numbers from publicly available federal electronic court filings).
} 
censorship if he runs up against the Bambauer Act's constraints on hard censorship? Is it possible that the Bambauer Act is too legitimate?

3. The question can also be put in institutional terms. Would the passage of the Act affect judges' willingness to countenance soft censorship? Would their sympathy for softcensorship techniques of evasion and deception decrease if the government had available a statute on point that it declined to proceed under? Or would the same institutional factors that currently make the courts poor guardians against pretext, payment, and persuasion continue to hinder them even with the Bambauer Act on the books? Could the Act increase courts' deference to executive acts of soft censorship by declaring a public policy that explicitly tolerates some forms of censorship? Does the answer depend on how the Act is drafted? How should a principled judge attempt to resolve such questions? Should the Bambauer Act be regarded as an institutional settlement of the censorship question?

4. Is Professor Bambauer's preference for hard censorship over soft based on an assumption that the level of online filtering is exogenous to the choice of mechanism? It can hardly be gainsaid, can it, that all else being equal we should prefer the more legitimate form of censorship? But is it not equally plausible to say that the level of online filtering is itself in large part determined by the mechanisms available? Does legitimate censorship legitimate censorship? 